\title{
The Changing Regulatory SCHEME IN NORTHEAST BRITISH COLUMBIA
}

\author{
WALLY BRAUL*
}

The Northeast British Columbia (NEBC) oil patch is undergoing a boom in land tenure sales, exploration, and production. This comes at a time of increasing public concern over the use of hydraulic fracturing (or "fracking"), an unconventional technology that ushered in a new era of production in NEBC, along with several new contentious issues. Recently, four significant regulatory changes have been enacted or planned for the immediate future. The first, likely in response to public concern over fracking, occurred in October 2010 with an overhaul of the decades-old Petroleum and Natural Gas Act and the coming into force of the bulk of the provisions in the Oil and Gas Activities Act. The changes primarily affect production and environmental management, and several new provisions have a direct impact on fracking. The second change under development is the creation of a long-awaited groundwater licencing regime, marking a stronger environmental presence in the $N E B C$, and possibly abrogating pre-existing extraction rights. The third change arises from the expiry of Crown-First Nation Consultation Process Agreements (CPAs). Recent jurisprudence continues to point to the need for improved consultation and accommodation, but current negotiations may or may not succeed in arriving at a more comprehensive successor to the expired CPAs. Finally, under British Columbia's contaminated sites regime, new measures expand the liability exposure of oil patch operators for contaminated sites in both civil actions and government enforcement proceedings.
Le champ pétrolifère du nord-est de la ColombieBritannique connaît une période de prospérité en ce qui concerne les ventes foncières, l'exploration, et la production. Cette période de prospérité arrive à un moment où l'opinion publique s'inquiète de plus en plus de l'utilisation de la fracturation hydraulique, technologie peu courante qui a inauguré une nouvelle ère de production dans cette région, en plus de soulever quelques nouvelles questions litigieuses. Tout dernièrement, quatre changements réglementaires importants ont été mis en place ou prévus pour un avenir proche. Le premier changement, qui résulte sans doute des inquiétudes du public à l'égard de cette fracturation, s'est produit en octobre 2010 avec la révision de la Loi sur le pétrole et le gaz naturel qui existait depuis des décennies et l'entrée en vigueur de la majorité des dispositions de la Loi sur les activités pétrolières et gazières. Les changements touchent essentiellement la gestion de la production et de l'environnement; d'ailleurs, plusieurs nouvelles dispositions affectent directement la fracturation. Le deuxième changement en cours est la création d'un régime de permis très attendu relatif à la nappe, soulignant la forte présence environnementale dans cette région et peut-être même l'annulation de droits d'extraction préexistants. Le troisième changement découle de l'expiration des Ententes de processus de consultation entre la Couronne et les Premières nations. Une récente jurisprudence continue de faire ressortir le besoin d'améliorer la consultation et l'adaptation, mais les négociations en cours pourraient aboutir à un successeur plus général des Ententes échues. Enfin, en vertu du régime relatif aux sites contaminés de la Colombie-Britannique, de nouvelles mesures élargissent l'exposition à la responsabilité des exploitants du champ pétrolifère pour les sites contaminés à la fois sur le plan des poursuites civiles que des mesures gouvernementales d'application.

\section{TABLE OF CONTENTS}

I. INTRODUCTION . . . . . . . . . . . . . . . . . . . 370

II. The New OIL AND GAS ACtivities ACt REgime . . . . . . . . . . . . . . . 372

A. THE OGAA's CONTINUATION OF THE OGC

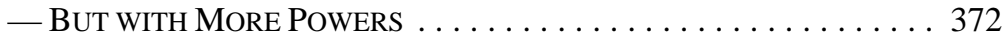

Wally Braul is a Partner at Fraser Milner Casgrain LLP and practises environmental, Aboriginal, and regulatory law. Most of his current work involves conventional gas, shale gas, pipeline, and independent power projects in British Columbia. The author acknowledges with thanks the assistance of Josh Fraese, Articling Student at Fraser Milner Casgrain LLP, Calgary. 
B. New Fracking Rules $\ldots \ldots \ldots \ldots \ldots \ldots$. . . . . . . . . . 374

C. NEW NotificAtion ANd CONSUltation REQUiREMENTS . . . . . . 377

D. Determinations, Reviews, AND APPEALS . . . . . . . . . . 378

E. Administrative Penalties . . . . . . . . . . . . . . . . . . . 379

III. The CONTEMPlated GROUNDWATER LiCENCING REgime . . . . . . . . . . 379

A. The Growing Demand for GROUNDWATER . . . . . . . . . . . . . 379

B. The Oil Patch Groundwater Regime in a Nutshell . . . . . . 380

C. The LAW Reform Program $\ldots \ldots \ldots \ldots \ldots \ldots \ldots$

D. THE IMPACT OF A NEW GROUNDWATER LiCENCING REGIME ON EXISTING OIL PATCH EXTRACTIONS . . . . . . . . . . . . . . . 382

IV. Consultation Process AgreEments $\ldots \ldots \ldots \ldots \ldots \ldots \ldots \ldots . \ldots \ldots 7$

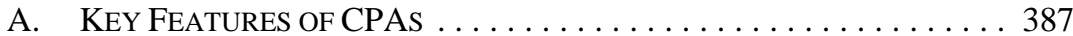

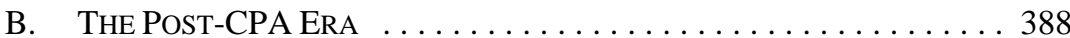

C. The PossibiLity of Litigation $\ldots \ldots \ldots \ldots \ldots \ldots$

V. Contaminated Sites . . . . . . . . . . . . . . . . . . . . . . . . . . . . 390

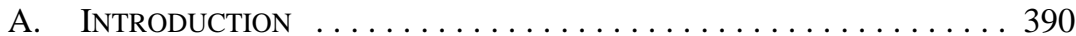

B. RECENT NEW STANDARDS OF “CONTAMINATION” . . . . . . . . . . . 391

C. STRICTER APPROACHES FOR INVESTIGATING POTENTIAL GROUNDWATER CONTAMINATION . . . . . . . . . . . 393

D. Liability ManAgEMENT Rating PROGRAM . . . . . . . . . . . . 393

E. New Rules Addressing Off-Site Migration . . . . . . . . . . . . . 394

F. NEW MEANS OF IDENTIFYING RISK . . . . . . . . . . . . . . . . . . . . 394

G. ORPHAN SITES . . . . . . . . . . . . . . . . . . . . . 395

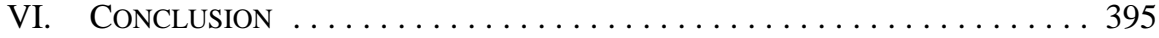

\section{INTRODUCTION}

The Northeast British Columbia (NEBC) oil patch is undergoing a boom in land tenure sales, exploration, and production. From 2006 to 2008, Crown petroleum and natural gas rights purchased in the Horn River Basin alone increased about eightfold from approximately $\$ 126$ million to almost \$1.1 billion. ${ }^{1}$ British Columbia saw one of the single largest sales of exploration land in Canada in 2010 with \$404 million raised in a single auction, as companies acquired large tracts of land for shale gas exploration. ${ }^{2}$ Lower gas prices have slowed exploration, but major industry tenure holders (often with offshore investors)

$1 \quad$ Christopher Adams, “Shale Gas Activity in British Columbia: Exploration and Development of BC’s Shale Gas Areas” (Presentation delivered at the 4th Annual Unconventional Gas Technical Forum, Victoria, BC, 8 April 2010), online: BC Ministry of Energy, Mines and Petroleum Resources <http:// www.empr.gov.bc.ca/OG/OILANDGAS/PETROLEUMGEOLOGY/UNCONVENTIONALGAS/Pa ges/Archives2010.aspx> at 15.

2 David Ebner, “B.C. shale gas gets jump-start with \$404-million land auction,” The Globe and Mail (24 June 2010) online: The Globe and Mail <http://www.theglobeandmail.com/report-on-business/bc-shalegas-gets-jump-start-with-404-million-land-auction/article1616371/>. 
continue to announce significant development plans to realize international market opportunities for natural gas-based products. ${ }^{3}$

This article discusses four significant regulatory changes that have recently been enacted or which are planned for the immediate future in the NEBC oil patch. The first of these changes occurred in October 2010 with the enactment of several new requirements respecting production, environmental management, reviews and appeals of regulatory decisions, and enforcement. These new provisions come at a time of increasing public scrutiny and concern over hydraulic fracturing (also referred to as “fracking” or “fraccing”) used in NEBC's shale gas plays.

The second key change is under development. The Province of British Columbia is currently preparing a substantive amendment to its water legislation that is intended, in part, to address a long-criticized gap, namely the absence of a groundwater licencing regime. A new groundwater licencing regime could have significant implications for the many NEBC fracking operations which extract large volumes from groundwater aquifers for shale gas production. A new licencing regime is expected in the next one to two years.

A third regulatory change arises from the 31 March 2011 expiration of Crown-First Nation Consultation Process Agreements. These five-year agreements formalized procedures and timelines for First Nation reviews of oil patch activity applications (up to 1,000 per year). The Crown, NEBC First Nations, and industry are currently assessing their options. First Nations are demanding a more deliberative form of consultation and accommodation for all applications against a backdrop of possible litigation alleging that the Crown is failing to discharge its constitutional duty to consult and accommodate. If successful, such litigation could result in rescission or suspension of Crown approvals to industry.

The fourth change is less prominent, but has substantial implications for environmental liability. Recent changes to British Columbia's contaminated sites regime appear to collectively increase the liability exposure of oil patch operators in both civil actions and government enforcement proceedings. Regulators and parties concerned about oil patch contamination may increasingly rely on these new provisions as recourse against oil patch operators.

Parts II to V discuss these regulatory developments.

3 The largest recent investment saw PetroChina pay CDN $\$ 5.4$ billion for a 50 percent stake in the Cutbank Ridge field, including assets in the Montney and Cadomin plays. Encana, News Release, "Encana to establish joint venture with PetroChina through sale of 50 percent interest in Cutbank Ridge business assets for C $\$ 5.4$ billion” (9 February 2011) online: Encana <http://www.encana.com/news/ newsreleases/2011/0209-petrochina-jointventure.html>. See also “Talisman, Sasol in second B.C. deal," CBC News (8 March 2011) online: CBC News <http://www.cbc.ca/news/business/story/2011/03/08/ talisman-sasol-bc-shale-gas.html>. 


\section{The New OIL AND GaS ACtivities ACt REgime}

Until 4 October 2010, the Petroleum and Natural Gas Act ${ }^{4}$ served as the primary, if not exclusive, source for regulating the NEBC oil patch. This changed when most of the new Oil and Gas Activities Act ${ }^{5}$ sections came into force.

One effect of the OGAA was to substantially limit the scope of the PNGA. Many PNGA provisions, particularly those governing oil patch operations and environmental management, were repealed and transported into the $O G A A$ with new, stricter terms. Today's version of the $P N G A^{6}$ and its regulations are limited to Crown land access, tenure, royalties, and surface rights matters. To the extent that changes were made to these areas, they are relatively minor.

The major changes to the regulatory scheme are found in the OGAA. The new regulatory features include:

1. enhanced regulation-making powers of the British Columbia Oil and Gas Commission (OGC);

2. fracking requirements;

3. notification and consultation requirements;

4. rights to review and appeal OGC decisions; and

5. compliance and enforcement tools for the OGC.

These changes are discussed below.

\section{A. The OGAA's CONTINUATION OF THE OGC — BUT WITH MORE POWERS}

The Oil and Gas Commission Act ${ }^{7}$ of 1998 established the OGC. The clear intention of the OGCA was to establish the OGC as the primary regulator of the oil patch. ${ }^{8}$ The $O G A A$ repealed the $O G C A$ and replicated the OGC provisions within the OGAA, maintaining the intention to have the OGC serve as the key provincial oil patch regulator.

\section{RSBC 1996, с 361 [PNGA].}

SBC 2008, c 36 [OGAA]. The OGAA received Royal Assent on 29 May 2008. Most, but not all, of the OGAA sections came into force through BC Reg 274/2010 [OGAA General Regulation]. Some sections came into force earlier, and other sections have not yet come into force, or have been repealed. The sections that are not yet in force are sections 124, 131 (part), 132-42, 143 (part), 154-59, and 171. Section 113 is being repealed, effective 3 October 2012.

Supra note 5 as amended by OGAA, ibid, ss 152-99.

SBC 1998, c 39, as repealed by OGAA, supra note 5, s 150 [OGCA].

The British Columbia Oil and Gas Commission (OGC) assumption of many powers ordinarily exercised by other ministries is formalized in: British Columbia, Provincial Sub-Agreement Memorandum of Understanding between the Oil and Gas Commission, Ministry of Environment, Ministry of Agriculture and Lands and the Ministry of Energy, Mines and Petroleum Resources (5 November 2008), online: OGC <http://www.bcogc.ca/publications/news/2008.aspx> 
A more significant change reflected in the OGAA is that the OGC has been given substantially more powers, particularly with respect to enacting regulations covering a wide range of oil and gas activities. ${ }^{9}$ The $O G A A$ maintains, in section 160 , the OGC's general authority to pass regulations "governing the methods and manner and places in which geophysical exploration may be carried out," 10 from the repealed OGCA, and supplements it with regulation-making powers on specific matters. Notably, these include: notification and consultation (section 107 of the $O G A A$ ), operator information and records (section 108), security (section 109), levies and penalty charges (section 110), technical aspects of exploration and production (sections 111-12) and "different regulations for different persons, places, things, decisions, transactions or activities” (section 106). ${ }^{11}$

The legislative intention of these regulation-making powers is clear - OGC regulations are expected to be a fundamental source of regulatory controls. Indeed, the OGC under the new OGAA has already enacted six regulations. ${ }^{12}$

Allowing the regulator to enact regulations is in line with the powers enjoyed by Alberta's Energy Resources Conservation Board (ERCB) and the federal National Energy Board (NEB). The ERCB may enact regulations without the approval of Cabinet. ${ }^{13}$ The NEB's discretion does not extend that far, as regulations created by the NEB require the approval of the federal Cabinet. ${ }^{14}$ Regulations passed by the OGC do not require the approval of Cabinet. $^{15}$

This is not to suggest that all oil patch regulation-making powers are left to the OGC. Cabinet still has significant powers, both under the PNGA and the OGAA. Recent regulations passed by the Cabinet under the OGAA include the OGAA General Regulation, the Environmental Protection and Management Regulation, ${ }^{16}$ and the Administrative Penalties Regulation. ${ }^{17}$

OGAA, supra note 5, s 1(2) broadly defines the term "oil and gas activity" to mean:

(a) geophysical exploration,

(b) the exploration for and development of petroleum, natural gas or both,

(c) the production, gathering, processing, storage or disposal of petroleum, natural gas or both,

(d) the operation or use of a storage reservoir,

(e) the construction or operation of a pipeline,

(f) the construction, use or operation of a prescribed road, and

(g) the activities prescribed by regulation.

Ibid, s 160.

Ibid, s 106-112.

Since the enactment of the OGAA the OGC has adopted: Consultation and Notification Regulation, BC Reg 279/2010 [CNR]; Drilling and Production Regulation, BC Reg 282/2010 [DPR]; Fee, Levy and Security Regulation, BC Reg 278/2010; Geophysical Exploration Regulation, BC Reg 280/2010; Pipeline and Liquefied Natural Gas Facility Regulation, BC Reg 281/2010; and the Prescribed Roads Regulation, BC Reg 8/2011.

13 Except for those regulations pertaining to security. Energy Resources Conservation Act, RSA 2000, c E-10, s 50.

National Energy Board Act, RSC 1985, c N-7, ss 52, 56.

OGAA, supra note 5, s 106(2).

BC Reg 200/2010 [EPMR].

BC Reg 35/2011 [APR]. 


\section{B. NEW FRACKING RULES}

\section{THE GROWING CRITICISM OF FRACKING}

A key driver behind the NEBC boom is the new natural gas production technology of fracking of shale formations. Fracking requires the high pressure injection of large volumes of water and proppant chemicals ( 0.5 percent of the water) into deep, horizontally drilled wells to essentially fracture the shale and thus release natural gas. The proppant is a hard substance used to keep the cracks open after the fracking pressure is reduced and is typically composed of silica, ceramics, or a resin-coated material. ${ }^{18}$ After the shale is fracked, the released natural gas and production water (with the constituent fracking chemical) are collected by a production well. Production water is stored in surface containers and in many situations is either reused in fracking or is disposed of by waste wells. ${ }^{19}$ By comparison, conventional gas production does not rely on the above-noted pressure, high volumes of water, and proppant.

Fracking has attracted strong public criticism. A commonly-cited critic of fracking in British Columbia is investigative journalist Ben Parfitt, the author of a University of Toronto study, Fracture Lines: Will Canada's Water be Protected in the Rush to Develop Shale Gas ${ }^{20}$ The Parfitt Report compiles many concerns of Canadian and US environmental groups. The Parfitt Report is, however, not the only critique of fracking. An increasing body of public criticism focuses on fracking's use of ground and surface water, the treatment of wastewater, and the possibility of uncontrolled contamination by proppant and saline production water of shallow freshwater aquifers and soils. ${ }^{21}$

\section{THE OGAA RESPONSE TO FRACKING ISSUES}

Fracking received some regulatory attention before the enactment of the OGAA in 2010. Certain requirements relevant to fracking were added from time to time in the PNGA's Drilling and Production Regulation. ${ }^{22}$

OGC, Fact Sheet, "Fracturing (Fraccing) and Disposal of Fluids” (November 2010), online: OGC $<$ http://www.bcogc.ca/document.aspx?documentID=1152> at 1 .

19 See further technical descriptions in ibid.

20 Ben Parfitt, Fracture Lines: Will Canada's Water be Protected in the Rush to Develop Shale Gas?, Program on Water Issues, Munk School of Global Affairs, University of Toronto (15 September 2010), online: Program on Water Issues <http://www.powi.ca/index_transboundary.php> [Parfitt Report].

21 See e.g. Fracking British Columbia, online: BC Tapwater Alliance <http://www.bctwa.org/Fracking BC.html>; Lisa Sumi, "Environmental Concerns and Regulatory Initiatives Related to Hydraulic Fracturing in Shale Gas Formations: Potential Implications for North American Gas Supply” Council of Canadians (21 September 2010), online: Council of Canadians <http://www.canadians.org/energy/ publications/index.html>; Randy Christensen, "Review of British Columbia's Groundwater Regulatory Regime: Current Practices and Opinions” Watershed Watch Salmon Society (14 February 2007), online: Watershed Watch Salmon Society <http://www.watershed-watch.org/publications/files/Groundwater_ Regulation_Review_SLDF.pdf>; Karen Campbell, Pembina Institute, "Natural Gas and Water: What You Need to Know about Hydraulic Fracturing in B.C.” (15 December 2010), online: Pembina Institute $<$ http://www.pembina.org/pubs/3>; BC Tapwater Alliance, News Release, "Public Inquiry Needed to Address Human Health and Environmental Risks Posed by Shale Gas Drilling, Coalition Says” (14 April 2011), online: BC Tap Water Alliance <http://www.bctwa.org/ FrackingBC.html>.

22 BC Reg 362/98 [PNGA DPR], as re-enacted by DPR, supra note 12. These requirements pertained to well casings, hydraulic segregation, recording of injected fluids, and reporting of produced water. 
These old PNGA fracking requirements, along with more recent requirements, were compiled in the OGAA's Drilling and Production Regulation. ${ }^{23}$ The new fracking rules that emerged in 2010 include:

- $\quad$ confidential well data and well reports from shale gas wells (classified as "special data wells") are to be publically released no later than "18 months after the date of release of the drilling rig"; ${ }^{24}$

- $\quad$ minimum depth for fracturing operations at 600 metres, unless the permit says otherwise; ${ }^{25}$

- $\quad$ reporting of water produced from wells and any flow back fluids, ${ }^{26}$ (supported by OCG Directive 2010-0 $07^{27}$ ); and

- unique spacing for "special projects,” such as shale projects. ${ }^{28}$

The OGC also enjoys regulatory tools to recognize unique physical conditions in the various shale plays in NEBC. ${ }^{29}$ Sections $75(4)$ and 111 of the OGAA enable the OGC to adopt regulations that could target specific shale gas plays with unique area-wide or projectwide requirements. ${ }^{30}$ Section $75(4)$, for example, allows the OGC to make regulations in relation to specified "special projects" that are inconsistent with or contradict other provisions of the OGAA. The need for this flexibility was already evident in the pre-OGAA PNGA. Section 100(1) of the old PNGA was used by the OGC to issue OGAA Order 10-15$001,{ }^{31}$ which approved the Liard-Besa River Development Scheme for that shale play (covering some $1,000,000$ hectares). ${ }^{32}$

Another source of potential regulatory requirements for fracking is the EPMR, adopted by Cabinet in October 2010. Part 3, Division 1 creates new rules relating to water quality, aquifer spacing, and restoration of sites no longer used for an oil and gas activity. ${ }^{33}$

DPR, supra note 12 .

OGAA General Regulation, supra note 5, s 17.

$D P R$, supra note 12 , s 21.

Ibid, s 70 .

OCG Directive 2010-07: Reporting of Water Production and Flow Back Fluids (Victoria: OGC, 2010). OGAA, supra note 5, s 75(3).

NEBC has three broad shale plays: Liard-Besa, Horn River Basin, and Montney.

For example, the OGAA lists shale gas projects as one of the specified types of oil and gas activities for which the OGC board may make regulations in relation to the "carrying out of an oil and gas activity" (section 111). For the purposes of section 75(4) of the OGAA, shale gas projects are included within the definition of "special projects" by section 10(2)(c) of the OGAA General Regulation.

OGC, Order 10-15-001 (12 March 2010).

Energy Resources Conservation Board (ERCB), Unconventional Gas Regulatory Framework Jurisdictional Review (Calgary: ERCB, 2011), online: ERCB <http:/www.ercb.ca/docs/Documents/ reports/r2011-A.pdf> at 30.

33 Supra note 16, ss 9-19. For instance, operators must ensure that activities on top of aquifers do not have an adverse effect on the water flow, flow rate, natural timing, or quality of the aquifer (section 10). Section 20 requires an operator to mitigate impacts of an oil or gas activity on water supply in adjacent areas where those impacts are unavoidable, as well as providing advance notice and an alternate supply to owners or users of the water supply. 


\section{FURTHER FRACKING REQUIREMENTS?}

One can reasonably conclude that, despite the above-noted OGAA changes, the public debate over fracking is far from over. Several key criticisms of fracking in NEBC have apparently not been addressed by the recent law reform. A common concern is that physical attributes of the NEBC aquifers are poorly understood, creating a risk that shallow fresh water aquifers could become contaminated by fracking fluids that migrate from deeper layers. $^{34}$

Another concern pertains to the handling of fracking fluids. The Parfitt Report recommends that "[a]ll flow-back fluids at hydraulically fractured wells should be captured, securely stored and then treated to a high enough standard that they can be re-used in subsequent fracturing operations." ${ }^{35}$ The OGAA or its regulations require safe management of flow back fluids but do not go so far as to require reuse. ${ }^{36}$

Another likely point of dispute is over access to information. The Parfitt Report recommends a publicly accessible system for tracking water extractions, including "how much toxic flow-back water is generated at each gas well site." 37 The OGAA General Regulation requires that all produced water be measured and reported, as well as all flow back fluids, but not immediately, allowing a delay for public release that varies from two months to three years. ${ }^{38}$

A final example of an unresolved concern is the lack of resource and land use planning. The Parfitt Report recommends creating “[n]o-go zones ... where hydraulic fracturing operations are banned outright or subject to more stringent reviews and approvals." ${ }^{39}$ It seems that this recommendation is partially addressed by the OGAA regime. Sections 4 to 7 of the EPMR sets out numerical and other standards that arguably define "no-go zones." A potential concern for environmental critics is that the EPMR allows an operator to seek a relaxation of these standards if the activity in question does not have a "material adverse effect." ${ }^{" 10}$ It remains to be seen whether the new standards themselves and the methods for determining "material adverse effect” will attract environmental group concerns. ${ }^{41}$

These, and perhaps other concerns, appear to be having some effect on lawmakers and regulators. It appears from recent (March 2011) news reports that both the OGC and the Minister of Energy and Mines have committed to enhanced regulation of fracking, going

$34 \quad$ Parfitt, supra note 20 at 41.

$35 \quad$ Ibid at 45.

The new $D P R$ requires all flow back fluids to be disposed of safely, in a manner that does not pose a risk of contamination to any "water supply well, usable aquifer, or water body" or land or water "frequented by fish or wildlife” (section 51(1)). Operators must also report on the disposal of flow back fluids and other drilling and production waste (section 51(4)).

Supra note 20 at 47 [emphasis omitted].

OGAA General Regulation, supra note 5, s 17. See also OGAA, supra note 5, s 38(2).

Supra note 20 at 47 [emphasis omitted].

Supra note 16 at ss $4-7$.

OGC, Environmental Protection and Management Guide, ver 1.2 (Victoria: OGC, 2011), online: OGC <http://www.bcogc.ca/document.aspx?documentID=927\&type=.pdf>, at 92 notes: "Information regarding 'material adverse effect' can be found in the Forest and Range Practices Act CEPS Bulletin 40, December 2009, 'Guidance to CE Program staff and delegated decision makers on interpreting the words 'material adverse effect' and 'material adverse impact,' available on the Ministry of Forests, Lands and Natural Resource Operations Website.” 
beyond the law reform enacted in October 2010. ${ }^{42}$ In April 2011, the Province of British Columbia announced that it was embarking on a study into health effects of NEBC petroleum operations. $^{43}$

The Province of British Columbia is not alone in reviewing the regulation of fracking. For example, the Province of Quebec recently announced a ban against fracking pending further study ${ }^{44}$ and in the US, the federal Environmental Protection Agency is increasing its scrutiny of fracking operators as well as the treatment of flow back fluids. The State of Pennsylvania, for example, has recently doubled the number of regulators, enhanced well design specifications, and limited the amount of flow back fluids that treatment plants may accept. ${ }^{45}$

\section{NEW NOTIFICATION AND CONSULTATION REQUIREMENTS}

The OGAA creates a new notification and consultation system applicable to a wide array of oil or gas activity applications made to the OGC. The OGAA essentially requires that applicants notify landowners of their intention to submit an application for an oil and gas activity on their land and inform them that they may make submissions to the OGC. ${ }^{46}$ The OGC's Consultation and Notification Regulation provides more detail, for example, by requiring that notifications be sent to parties located within specified distances from the site of the proposed activity. Those distances vary depending on the nature of the activity, but range from 200 metres for pipelines ${ }^{47}$ to 3,300 metres and beyond for a processing plant. ${ }^{48}$

The new regime also calls for consultation. Section 22(3) of the OGAA prescribes how applicants must in certain cases consult with aggrieved or concerned "eligible persons" 49

42 See e.g. Jeff Lee, “B.C. to continue ‘fracking' for gas, despite bans elsewhere” The Vancouver Sun (30 March 2011), online: Canada.com <http://www.canada.com/vancouversun/news/business/story.html?id =dcbe13ef-14a8-406c-aa53-98fa7b7e7ae0\&k-43154>.

43 Mark Hume, “Health probe planned for B.C.'s shale gas sector” The Globe and Mail (14 April 2011), online: Globe and Mail < http://www.theglobeandmail.com/news/national/british-columbia/health-probeplanned-for-bcs-shale-gas-sector/article1986263/>.

44 Kevin Dougherty, "Province halts fracking for oil and gas; Process can only be done for research" The Montreal Gazette (17 March 2011) at B1.

45 Ian Urbina, "Pressure Limits Efforts to Police Drilling for Gas” The New York Times (3 March 2011), online: NYTimes.com <http://www.nytimes.com/2011/03/04/us/04gas.html?pagewanted=all>; Ian Urbina, "Regulation Lax as Gas Wells' Tainted Water Hits Rivers” The New York Times (26 February 2011), online: NYTimes.com <http://www.nytimes.com/2011/02/27/us/27gas.html?pagewanted=all>; Andrew Maykeath, "Marcellus Shale drillers balk at EPA presure on state to tighten wastewater disposal rules” The Philadelphia Inquirer (13 May 2011), online: Philly.com < http://articles.philly.com/2011-0513/business/29540301_1_wastewater-disposal-marcellus-shale-coalition-drilling-wastewater>. OGAA, supra note 5, s 22(2).

CNR, supra, note 12 , s 8.

Ibid, s 6(2).

OGAA, supra note 5, s 69(1):

"eligible person" means

(a) an applicant for a permit,

(b) a permit holder or former permit holder,

(c) a land owner of land on which an oil and gas activity is permitted to be carried out under this Act,

(d) a person to whom an order under section 49 (1) has been issued, and

(e) a person with respect to whom the commission has made a finding of a contravention under section 62. 
within applicable time frames. ${ }^{50}$ The consultation requirement is new in the NEBC oil patch, but it follows the approach used in Alberta's oil patch legislation. ${ }^{51}$

Section 22(4) of the OGAA gives the OGC the discretion to substitute prescribed requirements with other consultation and notice requirements. Such a substitution occurred with respect to the OGC's Consultation Process Agreements with most NEBC First Nations. ${ }^{52}$ These agreements are discussed in Part VI.

\section{Determinations, ReVIEWS, AND APPEALS}

The OGAA sets out a new process for reviewing original OGC decisions (or “determinations"). "Eligible persons” may request a review of a determination by the OGC under section 70 of the OGAA. The person conducting the review is a "review official," who in practice will be a senior official at the OGC. ${ }^{53}$

A review official must, as soon as possible, "confirm, vary or rescind the determination" under review, and provide reasons for doing so to the person who requested the review. ${ }^{54}$ The review official must also notify the person of his or her right to appeal to the Oil and Gas Appeal Tribunal (the Tribunal). ${ }^{55}$

The Tribunal is newly established under section 19 of the OGAA. ${ }^{56}$ Constituted independently of the OGC, the Tribunal is authorized to hear appeals from section 70 reviews and, in certain cases, from other OGC determinations if no review was requested. ${ }^{57}$ The Tribunal's procedural rules are prescribed in the province's generic Administrative Tribunals Act. ${ }^{58}$

CNR, supra note 12, s 14(3). For example, if an applicant receives a written response to a consultation invitation, they must reply as soon as possible. If no responses are received, the applicant's duties in the way of consultation expire 21 days after the last consultation notice was sent. Otherwise, the time frame for consultation may be extended until the last written reply has been sent, or, if a meeting was requested, until after reasonable efforts have been made to conduct the last meeting requested. Once consultations have been completed, the permit application can be submitted along with a report on the results of the consultation process. OGAA, supra note 5, s 24(1)(c).

51 See ERCB, Directive 056: Energy Development Applications and Schedules (Calgary: ERCB, 2008) at A-49. The consultation requirements under the OGAA may prove to be more inclusive of stakeholders than the Alberta equivalent. For example, Table 6.1 of Directive 056 refers to various notification distances, including "Landowners, occupants, and residents within $1.5 \mathrm{~km}$ " and "Urban authorities within $3.0 \mathrm{~km} . ”$

52 These Agreements impose notification and consultation requirements on the OGC and industry applicants. The $C N R$ uses far more limited notification and consultation requirements respecting First Nations than are found in the Agreements, most of which expired on 31 March 2011.

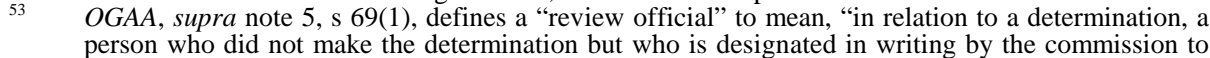
review the determination for the purposes of sections 70 and $71 . "$

Ibid, s 71(1).

Ibid, s 71(1)(b)(iii).

Ibid, s 70, states that a request for a review must be made before the determination is appealed to the appeal tribunal, and within 30 days of the determination or receiving written reasons for the determination. This time frame may be extended in special circumstances if failing to extend it would result in an injustice. The request for a review must be in writing and must identify the error that the person believes has been made.

$57 \quad$ Ibid, s 72, provides for appeals from reviews under section 71 if the appellant was a party to the review, and from determinations if the eligible person did not apply for a review under section 70(1) at the time of the appeal. It appears that parties can elect to have a determination reviewed by a review official under section 70 or section 71 first, or they can go straight to a tribunal appeal.

58 Ibid, s 20; SBC 2004, c 45. 


\section{E. Administrative Penalties}

The OGC has new authority to determine whether contraventions of the OGAA or its regulations have occurred. ${ }^{59}$ To do so, the OGC may exercise a new power (in sections 5762 ) to conduct inspections and audits. ${ }^{60}$ On finding a contravention, the OGC may exercise a further new power to impose monetary penalties, referred to as "administrative penalties" in the legislation. ${ }^{61}$ The OGC may impose monetary penalties for any contraventions of the $O G A A{ }^{62}$ The monetary penalty provisions are backed up with substantial civil liability sanctions - the OGC may enforce a penalty by registering it with the Supreme Court of British Columbia, and such registration is deemed to be a judgment of the court for the payment of a debt. ${ }^{63}$ The OGC may also make any orders it views as necessary to mitigate public safety risks. ${ }^{64}$ Section $62(5)$ of the OGAA recognizes due diligence, mistake of fact, and officially induced error as defences to prosecutions for any contraventions of the $O G A A .^{65}$ The power to enact regulations respecting penalties and related procedures is left with Cabinet. $^{66}$

The OGC's new administrative penalty powers supplement penalties available in prosecutions before the enactment of the OGAA, (that is, those penalties originally in the preOctober 2010 PNGA) and carried over into the OGAA. For example, a failure to restore the land and surface disturbed by the construction of a pipeline as required by section 35(3) is subject to a maximum penalty of $\$ 1,000,000$ or imprisonment for up to two years. ${ }^{67}$ Prosecution of these offences is the domain of Crown prosecutors, not the OGC. Section $87(2)$ of the $O G A A$ provides that a prosecution for a statutory offence may not be brought if an administrative penalty has been ordered for the same contravention. ${ }^{68}$

\section{The CONTEMPLATED GROUNDWATER LiCENCING REGIME}

\section{A. THE GRoWING DEMAND FOR GROUNDWATER}

Substantial volumes of water are needed for oil and gas production in NEBC. For example, large volumes of water are used to flood formation oil pools to enhance recovery and to frack shale gas formations. ${ }^{69}$ To date, much of the water used for fracking comes from surface sources. ${ }^{70}$

OGAA, ibid, s 62.

Ibid, ss 57-62.

Ibid, s 63. See the rules for creating and enforcing penalties (ibid, ss 62-68, 90, 92, 101).

Ibid, ss $62-68$ establish the framework for administrative penalties. The APR, supra note 17 , s 2, specifies the amounts of those penalties.

OGAA, ibid, s 66.

Ibid, $\mathrm{s} 49$.

Ibid, s 62(5).

Ibid, s 101.

Ibid, s 86(2).

Ibid, s 87(2). The OGAA carries over PNGA provisions respecting prosecutions for statutory offences and sets out the maximum penalties (with maximums to $\$ 1,500,000$ and three years of imprisonment). OGC, Oil and Gas Water Use in British Columbia (Victoria: OGC, 2010) at 7, online: OGC <http:// www.bcogc.ca/publications/reports.aspx> Ibid at 7-9. 
This reliance on surface water sources appears to be diminishing. One reason is cost; operators must often transport water considerable distances from surface water sources to fracking operations (likely explaining Talisman's proposal to construct a water pipeline from Williston Lake to the Montney shale play ${ }^{71}$ ). Another reason is that surface water approvals can be suspended or rescinded in the event of water shortages, as occurred during the drought of mid-2010. ${ }^{72}$

The OGC has recently instituted additional reporting requirements respecting extractions of surface water, ${ }^{73}$ enabling it to more closely monitor if and when surface water approvals should be limited. The regulatory concern over increased use of surface water suggests that operators, given the necessity of water in production, will increasingly rely on groundwater sources.

\section{B. The Oil Patch GroundWATER Regime in A NutShell}

Groundwater for natural gas and oil production purposes is extracted primarily from two sources: "source wells” and "production wells."74

These wells are subject to four sets of controls:

- $\quad$ drilling licencing under the PNGA's Petroleum and Natural Gas Drilling Licence Regulation, ${ }^{75}$ which for the most part addresses applications for and management of drilling tenures and locations;

- $\quad$ permitting of well construction under the OGAA's DPR (notably, sections 68.71 and 72);

- $\quad$ generic well construction rules found in the Groundwater Protection Regulation ${ }^{76}$ under the Water Act; ${ }^{77}$ and

71 “Northern B.C. fracking licence concerns critics,” CBC News (29 July 2011), online: CBC News <http://www.cbc.ca/news/canada/british-columbia/story/2011/07/29/bc-talisman-fracking.html>.

72 OGC, Directive 2010-05: Suspension of Surface Water Withdrawals (Peace River) (Victoria: OGC, 2010).

73 An example of the OGC concern over large volume surface extractions is reflected in OGC, Directive 2011-02: Changes in Section 8 Short Term Water Use Approvals (Victoria: OGC, 2011), which imposed new reporting requirements for surface water use. In a news release, OGC, News Release, 2011-02, "BC Oil and Gas Commission Improves Water Management Processes” (2 March 2011), the OGC stated:

Industry will be required to specify each point of diversion from where it wishes to withdraw water using a standard section 8 application [one-year surface water approvals]. This new reporting requirement will allow the Commission to better monitor water consumption by industry, translating into increasingly accurate reporting on water withdrawal locations and volume use.

74 "Production wells" are those used for the production of oil or gas and are typically the subject of a PNGA section 50 oil and gas lease. These leases contemplate that the lessee may produce water related to the production of oil or gas. "Source well” water can be supplemented with "produced water," and vice versa, in the production of oil or gas. See PNGA, supra note 4, ss 1, 50.

BC Reg 10/82.

BC Reg 299/2004.

RSBC 1996, c 483. 
- $\quad$ environmental controls over aquifers found in the EPMR. ${ }^{78}$

Conspicuously absent are controls governing extraction volumes. A volume licencing regime exists for surface water but not for groundwater in British Columbia. ${ }^{79}$ The enactment of a groundwater licencing regime requires a Cabinet regulation under the British Columbia Water Act. ${ }^{80}$ Such a regulation has not yet been adopted.

\section{The Law REForm Program}

The Ministry of Environment's “Water Act Modernization” (WAM) recognizes the need to reform the groundwater regime. ${ }^{81}$ A common theme of WAM's December 2010 report, Policy Proposal on British Columbia's New Water Sustainability Act, ${ }^{82}$ is the need for a licencing regime for large water extractions. The report states, for example: “Groundwater extraction and use will be regulated in problem areas and for all large groundwater withdrawals across BC. All existing and new large groundwater users throughout the province will be required to obtain a licence or an approval.",83

The enactment of a groundwater regime in the near future is also supported by British Columbia's Auditor General. The Auditor General's December 2010 report, An Audit of the Management of Groundwater Resources in British Columbia, generally supported the directions taken by the WAM initiative of the Ministry of Environment, including a regime to allocate groundwater extraction rights. ${ }^{84}$

Many uncertainties remain, however. WAM does not provide a schedule for when the recommended licencing regulation might be enacted. The timing of a new groundwater law regime is in part contingent on the development and likely further stakeholder consultation with respect to the details of a proposed licencing regime, though no such details have been disclosed.

Supra note 16, s 10, requires that persons carrying out oil and gas activities on top of an aquifer must not "cause a material adverse effect on the quality, quantity or natural timing of flow of water in the aquifer." Section 34 provides that the minister responsible for administering the Water Act may issue an order identifying an aquifer or groundwater recharge area.

79 This is unlike many other provinces, including Alberta. Groundwater licencing in Alberta is a comprehensive regime covering the many activities set out in the Water (Ministerial) Regulation, Alta Reg 205/1998, enacted pursuant to the Water Act, RSA 2000, c W-3.

The BC Water Act, supra note 77, s 1.1 [emphasis added], limits regulatory controls over groundwater as follows:

1.1 (1) Subject to a regulation under subsection (2), Part 2 [Licensing, Diversion and Use of Water and Related Matters] and Part 3 [Water Users' Communities] of this Act do not apply to ground water.

(2) The Lieutenant Governor in Council may, by regulation, fix a day on and from which some or all of Parts 2 and 3 of this Act apply to ground water in British Columbia or in an area of British

Columbia the Lieutenant Governor in Council designates in the regulation. Some 900 stakeholder submissions were received in 2009 and 2010 and are summarized in Government of British Columbia, British Columbia's Water Act Modernization: Report on Engagement (Victoria: British Columbia Ministry of Environment, 2010), online: Water Act Modernization <http://www. livingwatersmart.ca/water-act/submissions/>.

82 Government of British Columbia, British Columbia's Water Act Modernization: Policy Proposal on British Columbia's New Water Sustainability Act (Victoria: British Columbia Ministry of Environment, 2010), online: Water Act Modernization <http://www.livingwatersmart.ca/water-act/submissions/>.

$83 \quad$ Ibid at 9.

84 Office of the Auditor General of British Columbia, An Audit of the Management of Groundwater Resources in British Columbia, Report 8 (Victoria: Office of the Auditor General, 2010). The report states at page 2 that "control over access to groundwater is insufficient to sustain the resource and key organizations lack adequate authority to take appropriate local responsibility." 


\section{THE IMPACT OF A NEW GROUNDWATER LiCENCING REgIME ON EXISTing OIL PATCH EXTRACTIONS}

The enactment of a groundwater licencing regime may mean that oil patch operators will be required to substantially reduce groundwater extractions to meet licence requirements. Indeed, if the Parfitt Report is any indication, critics of fracking may push for significant reductions in groundwater extraction volumes to be formalized in licences.

The possibility of significant reductions in groundwater extractions raises the following questions:

1. What rights cloak the current (pre-licencing) extractions?

2. Do such rights provide a basis for seeking recourse against the Province of British Columbia (for example, damages) if the licencing regime adversely restricts the operator's business? In other words, is a remedy for damages available to oil patch operators who are required to make do with significantly less groundwater extractions?

These questions have not been addressed by legislation or case law, at least not directly. Unlicenced groundwater extractions in the oil patch are, to use the Water Act terminology, "unrecorded." ${ }^{\prime 5}$ The Water Act, however, does not explain the nature of the legal right, if any, that is associated with extracting unrecorded groundwater.

Some judicial commentary on unrecorded rights is found in the British Columbia Court of Appeal decision of Steadman v Erickson Gold Mining Corp. ${ }^{86}$ This decision sets out the general principle that unrecorded use of water amounts to a "right," albeit a "fragile” one:

This plaintiff had a right to the use of the water. It was a fragile right that only lasted so long as there was no person with a licence to use the water. In the meantime the plaintiff could use the water and could claim against others who interfered with that use without authority. He had the right to use the water that he did not own just as he had the right to breathe the air that he did not own. His right was somewhat like the right to use ground water. ${ }^{87}$

The case involved surface water, but the Court stated in obiter dicta that the same principle would apply to groundwater (acknowledging that the province has not yet enacted a groundwater licencing regime). ${ }^{88}$ Steadman, however, provides little guidance other than to say that the particular extraction in that case is "fragile" in the face of subsequent licencing requirements. Significantly, the Court provided little guidance in developing a response to a particularly relevant question in the oil patch context: Does the strength of an extraction right depend on whether the extraction is from a "production well" or a "source well"? As

Water Act, supra note 77, s 1, defines "unrecorded water" as "water the right to the use of which is not held under a licence or under a special or private Act."

(1989), 56 DLR (4th) 577 (BCCA), rev'g (1987), 43 DLR (4th) 712 (BCSC) [Steadman].

Ibid at 582 [emphasis added].

Ibid at 578-79. 
discussed below, there may be significantly different rights — and remedies — associated with these two types of wells. As a result, all extraction rights might not be created equally.

\section{PRODUCTION WELL EXTRACTION RIGHTS UNDER A NEW LICENCING REGIME}

A lease issued under section 50 of the PNGA provides a producer with "title" to the subject oil and gas resources. Under section 50, the Crown conveys to the lessee an exclusive right to produce oil and gas at the lease location. Under section 50(2), the Crown also conveys a right to "water produced in relation to the production of petroleum or natural gas" at the lease location, and the lessee enjoys a seemingly broad right to "store or dispose" of the produced water. ${ }^{89}$ As discussed in Part II.B.1, produced water is commonly stored and then disposed (that is, reused) in fracking operations. The British Columbia Legislature was arguably cognizant of the importance of groundwater extraction to production in respect of section 50 leases.

There are no cases confirming that lessees enjoy rights to extract groundwater in the course of and for the purpose of producing oil or gas. But assuming that the Crown in fact conveys such rights to section 50 lessees, the following questions arise: What is the nature, or strength, of the right to extract production water? Does the right to "store or dispose" produced water impliedly give the lessee wide discretion to extract whatever volume of groundwater is necessary for production of gas (for example, subsequent fracking)? Is the right to extract production water assertable against the Crown or third parties?

The PNGA does not address these questions, but some guidance can be found in the common law. Common law cases in Canada have unequivocally held that an oil and gas lease conveys to the lessee a profit à prendre,$^{90}$ translated literally, a 'right to take.' More specifically, a profit à prendre "is a right to enter the land of another and to take some profit from the soil or any part of the soil itself," 91 and is, in addition, a recognized category of real property..$^{92}$ Applying the profit à prendre concept to a PNGA oil and gas lease, the province essentially conveys a real property right to enter a formation and capture certain Crownowned oil and gas.

What is less certain, particularly given the dearth of case law in the area, is whether a PNGA section 50 lease impliedly gives the lessee a profit à prendre to extract groundwater in the course of producing oil or gas. If, however, oil and gas lessees have an incidental profit à prendre to produced water, then the question becomes whether this real property right is enforceable against a future groundwater licencing regime. These lessees might have legal recourse in two ways:

See Berkheiser v Berkheiser, [1957] SCR 387; John Bishop Ballem, The Oil and Gas Lease in Canada, 4th ed (Toronto: University of Toronto Press, 2008) at 15.

Bennett Jones \& Nigel Bankes, Canadian Oil and Gas, 2d ed, loose-leaf (consulted on 11 August 2011) (Markham, ON: LexisNexis Canada Inc, 1993) vol 1 at para 2.39.

Bruce Ziff, Principles of Property Law, 5th ed (Toronto: Carswell, 2010) at 76. 
- $\quad$ De facto expropriation. The Supreme Court of Canada in $R v$ Tener $^{93}$ held that the denial of a park permit meant that access to the respondents' mineral rights (a profit à prendre) were completely negated or, as Justice Wilson put it, amounted to total denial of the interest in those mineral rights. ${ }^{94}$ Other decisions have reached similar conclusions. ${ }^{95} \mathrm{~A}$ common theme of these decisions is that the de facto expropriation doctrine is limited to real property rights. ${ }^{96}$

These decisions are also highly fact-dependent, making it difficult to project the specific circumstances in which a section 50 lessee could successfully obtain redress for de facto expropriation. What is clear, however, is that de facto claims have succeeded in other cases and at the very least, might be raised in the current law reform process.

- $\quad$ Breach of contract. John Ballem's authoritative text, The Oil and Gas Lease in Canada, observes that oil and gas leases constitute enforceable contracts. ${ }^{97}$ Neither the PNGA or the provincial government standard form section 50 lease appear to contemplate that the province has the right to unilaterally breach the lease, whether by legislation or some other act. The issue therefore is whether the province, as a contracting party, has the prerogative to use legislation to substantially limit or extinguish the benefits of the lease contract, namely the right to extract produced water.

British Columbia (AG) v Esquimalt \& Nanaimo Railway Co ${ }^{98}$ held that a government cannot contractually bind itself not to enact legislation; that is, legislation will not be struck down even if it creates a compensable breach. In the event of such a breach, Stephen Waddams summarizes the case law as follows:

\footnotetext{
[T] he sovereignty of Parliament is not diminished by holding that the enactment of a particular piece of legislation gives rise to an action for damages for breach of contract. The legislation remains valid and generally applicable according to its terms. The Crown is simply required to pay compensation. ${ }^{99}$
}

In the NEBC oil patch context, the starting point for assessing whether a water licence condition has the effect of breaching a lessee's right to produced water

\section{[1985] 1 SCR 533 [Tener].}

\section{Ibid at 552.}

In Casamiro Resource Co v British Columbia (AG) (1991), 80 DLR (4th) 1 (BCCA), which closely resembles Tener, the British Columbia Court of Appeal held at page 11 that the subject mineral rights had become "meaningless." Mariner Real Estate Ltd v Nova Scotia (Attorney General) (1999), 178 NSR (2d) 294 (CA), while not disagreeing with the above-noted decision, illustrates the judicial deference to legislative intention. In that case, landowners had their plots classified as "beach" and were denied permits to build single-family homes on their land. The Court held that since the owners could still use the land for camping and other low-intensity uses, as they had been doing for years previous to the reclassification, they still had their property rights, and thus compensation was not required. Nilsson, 1999 ABQB 440, 246 AR 201 at para 48 [Nilsson], which stated that de facto regulatory expropriation occurs when a regulation "is of sufficient severity to remove virtually all of the rights associated with the property holder's interest.” 
would be a careful consideration of whether compliance with a groundwater licence unavoidably damages the lessee's contractual right to produce oil or gas. ${ }^{100}$

\section{SOURCE WELL EXTRACTION RIGHTS UNDER A LICENCING REGIME}

Not all oil patch groundwater extraction is conducted in the context of section 50 leases. For example, a producer may originally produce gas and water under a lease, but upon finding that the well no longer produces gas continues to use the well exclusively for groundwater extraction. Or, an operator may drill a source well for the exclusive purpose of extracting groundwater, which is then piped or trucked to another site for fracking purposes.

The key questions arising for these (non-section 50 lease) extractions are: do drilling licences and well permits convey property rights to extract groundwater? If not, what rights (if any) are acquired in this scenario?

These questions are not apparently addressed in the legislation. However, a starting point for considering whether licences and permits convey a property right is the common law principle that conveyance of such a right must be reasonably clear. The courts apply a strict test when determining the existence of a property right; there is considerable judicial reluctance to create a property right by mere implication and without reasonable certainty. ${ }^{101}$ Such reasonably clear language does not appear to exist in well permits and drilling licences. A court might also draw an adverse inference from the fact that the legislature intended to create profit à prendre rights in a limited way, that is, expressly for "water produced in relation to the production of petroleum or natural gas"102 in the context of section 50 leases, but remained silent on other extractions that might be conducted by producers.

At most, the drilling licensee or well permittee is arguably allowed to do something that would otherwise be a common law trespass if such an action was brought by the Crown, particularly since the Water Act deems ownership of groundwater to rest with the Crown. ${ }^{103}$ The common law appears to recognize such rights, describing them as "bare licences" (or "mere licences”). Halsbury describes the common law "bare licence” right as follows:

Ibid [footnotes omitted]:

It might well be held that a statute of general application was not intended to relieve the Crown of contractual obligation, and in case of doubt, it would seem that the legislation should be construed against such an implied derogation of rights. The freedom of the legislature to act in the public interest is not denied, but the presumption should be that where the public interest is attained at the expense of an individual, the individual's rights to compensation should remain intact.

For example, the real property right of a profit à prendre can be created by either "grant" (whether by statute or by contract) or "prescription": Anne Warner La Forest, Anger \& Honsberger Law of Real Property, 3rd ed, loose-leaf (consulted on 10 August 2011) (Aurora: Canada Law Book, 2010) vol 2 at 17:30.10; Race v Ward (1855) 4 El \& Bl 702; Duke of Sutherland v Heathcote, [1892] 1 Ch 475 (Eng $\mathrm{CA}$ ) at 484-85; Kevin Gray \& Susan Francis Gray, Elements of Land Law, 4th ed (Oxford: Oxford University Press, 2005) at 8.128. Acquiring a real property right by prescription does not apply to groundwater, given the Water Act's prohibition of prescriptive water rights: Water Act, supra note 76, s 2(2). 
A bare licence which does not amount to a profit à prendre, such as a licence to search for minerals, confers upon the grantee no property in the minerals found. ${ }^{104}$

Profits à prendre, though sometimes called "licences", must be carefully distinguished from mere licences, which are not tenements and do not pass any interest or alter or transfer property in anything, but only make an act lawful which otherwise would have been unlawful. A mere licence is not transferable, nor can it be perpetual; it is not binding on the tenement affected, but is a personal matter between the licensor and the licensee. It is generally revocable and merely excuses a trespass until it is revoked. ${ }^{105}$

To use the Halsbury analysis, the province arguably engages in a "personal matter" when it issues a drilling licence or a well permit to allow an operator to extract water that would otherwise be an actionable trespass to the province's groundwater.

An instructive example of how the courts "read down" rights found in approvals is found in the Alberta Court of Appeal decision of Musselman v Zimmerman, ${ }^{106}$ which held that a person is a "bare [or mere] licensee" if he or she is "merely permitted by the owner to enter" and the owner has the right to revoke the permission at any time. ${ }^{107}$ The NEBC groundwater regulatory regime similarly leaves the province, as owner of the water, with broad revocation rights. This was amply illustrated in the summer of 2010 when the OGC suspended many Water Act surface extraction approvals. Permits for oil and gas activities are likewise subject to cancellation, suspension, or amendment by the OGC (subject to certain opportunities to be heard). ${ }^{108}$

The potential remedies available to bare licensees would likely be governed, at least in part, by the following considerations:

- De facto expropriation. It seems that the common law doctrine of de facto expropriation is limited to real property rights, as noted by Tener and Nilsson (as discussed above in footnotes 92, 94, and 95 and in the accompanying text), and thus would not be available to "bare licensees."

- $\quad$ Breach of contract. It may be that bare licensees have contractual remedies. Goodyear Tire \& Rubber Co of Canada Ltd v T Eaton Co Ltd ${ }^{109}$ states that breach of requirements under a licence issued as part of a compulsory licencing regime can give rise to contractual remedies. Bayer Aktiengesellschaft v Apotex Inc similarly stated that "[i]n a compulsory licensing regime, common law remedies for a breach of contract will remain unless clearly displaced by the language of the licence."110 [footnotes omitted]. [footnotes omitted, emphasis added].

106 (1922), 66 DLR 350.

$107 \quad$ Ibid at 351.

108 OGAA, supra note 5, s 26.

109 [1956] SCR 610.

$110 \quad$ (1998), 113 OAC 1 at para 31. 


\section{Consultation Process Agreements}

A central feature of the oil patch regulatory regime since 2006 - at least until 31 March 2011, as discussed below — was the presence of Consultation Process Agreements (CPAs) between the OGC (representing the Crown), seven NEBC First Nations, and one Alberta First Nation (the Dene Tha', whose territory extends to NEBC). ${ }^{111}$ These template agreements essentially established procedures by which First Nations may review oil patch activity applications.

The CPAs appeared to respond to a growing body of case law respecting the Crown's constitutional duty to consult. For example, the 1999 British Columbia Court of Appeal decision in Halfway River First Nation v British Columbia (Ministry of Forests) ${ }^{112}$ quashed a provincial cutting permit in NEBC, necessary for related oil patch activities, for failure to consult. The Court quashed the permit because the Crown failed "to provide in a timely way information the aboriginal group would need in order to inform itself on the effects of the proposed action, and to ensure that the aboriginal group had an opportunity to express their interests and concerns." 113 This and other decisions ${ }^{114}$ influenced a significant policy change on the part of the Province of British Columbia, culminating in a series of "New Relationship" agreements in 2005 and 2006 with First Nations umbrella organizations. ${ }^{115}$ The CPAs were part of this larger policy change.

\section{A. KEY FEATURES OF CPAS}

The CPAs have the express "intent of avoiding or mitigating any potential infringements of the treaty rights" and are "not intended to create, recognize, affirm, limit, deny, derogate or aborgate any aboriginal or treaty rights within the meaning of sections 25 and 35 of the Constitution Act, 1982. ${ }^{116}$ The CPAs are agreements between the Crown and First Nations, although they contemplate certain roles for applicants.

CPAs pertain to a wide range of oil and gas activities, including seismic testing, construction of well sites, access roads, pipelines, and processing facilities. The OGC

The seven First Nations signing in 2006 were the Halfway River First Nation, Saulteau First Nations, West Moberly First Nations, Prophet River First Nation, Doig River First Nation, Fort Nelson First Nation, and the Dene Tha' First Nation. OGC, Information Letter 07-12, “Cover Letter for First Nations (referral) Packages covered by New Consultation Process Agreements” (17 April 2007). The McLeod Lake First Nation CPA was signed in 2008. 1999 BCCA 470, 178 DLR (4th) 666.

Ibid at para 165 .

See Haida Nation v British Columbia (Minister of Forests), 2004 SCC 73, [2004] 3 SCR 511; Mikisew Cree First Nation v Canada (Minister of Canadian Heritage), 2005 SCC 69, [2005] 3 SCR 388. See also West Moberly First Nations v British Columbia (Ministry of Energy, Mines and Petroleum Resources), 2010 BCSC 359, 6 BCLR (5th) 94, where the key failing related to accommodations rather than consultation.

115 See Government of British Columbia, Government of Canada, and The Leadership Council Representing the First Nations of British Columbia, Transformative Change Accord (25 November 2005), online: Transformative Change Accord <http://www.newrelationship.gov.bc.ca/agreements_and_ leg/trans_change_accord.html>; Province of British Columbia and Métis Nation British Columbia, Métis Nation Relationship Accord (12 May 2006), online: Métis Nation Relationship Accord <http://www. newrelationship.gov.bc.ca/agreements_and_leg/metis_relationship_accord.html $>$.

116 Consultation Process Agreement, Dene Tha' First Nation and British Columbia, 2 October 2006, ss 1.2, 2.1. Constitution Act, 1982, being Schedule B to the Canada Act 1982 (UK), 1982, c 11, s 35. 
reported that over 1,000 applications were reviewed in a 12-month period between 2009 and $2010 .{ }^{117}$

Each CPA refers to the signatory First Nation's Key Response Area (KRA). The signatory First Nation has the right to respond to applications falling with its KRA. KRAs appear to correspond to traditional territories of signatory First Nations, although this is not expressly confirmed in the CPAs or related documents.

A key feature of the CPAs is that the OGC must provide information about oil and gas activity applications to relevant First Nations and the First Nations may then respond within prescribed time frames. Signatory First Nations may respond within 10 days for "standard" applications and 20 days for applications deemed “complex."118

CPAs also provide capacity funding to enable First Nations to respond to applications sent by the OGC within the prescribed time frames. In exchange, First Nations agree not to require financial contributions from industry in relation to any proposed activities.

CPAs are equally important for what they do not cover. Most notably, they do not apply to projects that trigger federal or provincial environmental assessment, water infrastructure and pipelines (for example, Talisman's Williston water line to Montney), Water Act licence and approval applications, or higher-level policy and land use planning decisions, not directly associated with an oil or gas activity application.

\section{B. The Post-CPA ERA}

Six of the eight CPAs expired on 31 March 2011. It remains to be seen whether the Dene Tha' First Nation, whose CPA expires on 20 September 2011, will decline to renew. The same can be said for the McLeod Lake First Nation, whose CPA was signed in 2008 and expires on 30 April 2013.

First Nations have publicly expressed various concerns over the recently expired CPAs. The umbrella organization for many of the CPA signatories, the Treaty 8 Tribal Association, has complained about "the amount of time they have to assess development proposals and their capacity to effectively determine their impact." ${ }^{\text {"19 }}$ According to the Tribal Chief Liz Logan of the Tribal Association, the deadlines for First Nations to respond are too short to reliably contact land users who are out on the land or adequately assess the impact of a proposal. Chief Logan also objects to the OGC's lack of responsiveness to consultations with First Nations, as evidenced by the high application approval rate: "Over almost five years, the OGC has only rejected one proposal and approved the other 99.99 per cent.”120

OGC, 2009/2010 Annual Service Plan Report (Victoria: OGC, 2010) at 31.

Consultation Process Agreement, British Columbia and Fort Nelson First Nation, 1 December 2006, s 5.6.

Ryan Lux, “Treaty 8 wants new Consultation Process Agreement,” Alaska Highway News (7 April 2011), online: Alaska Highway News <http://www.alaskahighwaynews.ca/article/20110407/FORTST JOHN0101/304079998/-1/FORTSTJOHN/treaty-8-wants-new-consultation-process-agreement>.

Ibid. It is also possible that First Nations will demand increased funding to hire technical specialists, tailored consultation processes (not the templates used in the CPAs), an expansion in the scope of subject activities, an improved database of traditional land use, and amendments to KRAs to coincide with asserted traditional territories. 
The OGC anticipated that the First Nations would not commit to a renewal of the CPAs after 31 March 2011. On 1 April 2011, the OGC adopted the “draft” Interim Consultation Procedure (ICP). ${ }^{121}$ The ICP applies to all "Treaty 8 First Nations that are not party to an agreed upon process under a CPA or other agreement."

As for the "draft" status of the ICP, the OGC has stated that " $[\mathrm{t}]$ he draft ICP has been shared with the First Nations to provide opportunity for review and comment." 123 The status and extent of First Nations consultation on the ICP is not evident from public sources. Since the OGC treats the ICP as being in effect, the "draft" status may be nothing more than an indication that the ICP will be subject to change on short notice, pending the outcome of consultations. The OGC has also indicated that the ICP represents no substantial change for industry, stating that "[t]he primary change relates to the internal processes within the Commission and how the Commission engages with First Nations without CPAs.”124

The ICP is termed "interim" because the OGC continues to attempt to negotiate new CPAs that would displace the ICP. ${ }^{125}$ The OGC has not publicly stated how long this "interim" status will prevail. Negotiations for a CPA successor are confidential, but the OGC has indicated they are ongoing and at an early stage. ${ }^{126}$ The likely expectation for all parties the OGC, First Nations, and industry applicants — is that the ICP is a stop-gap measure that is subject to change.

The ICP itself does not address capacity funding, although it is possible that it could be provided confidentially.

The ICP does not substantially lengthen the time frames for initial First Nation responses. However, the ICP appears to apply a more deliberative approach than the CPAs using two stages (not found in the CPAs) designed to assess, using in-person consultations, effects on First Nation interests. ${ }^{127}$ These stages are not subject to timelines. ${ }^{128}$

It is still too early to tell whether the ICP approach will be successful. Many questions remain regarding CPAs and ICPs, including whether there will be changes to the "draft" ICP.

OGC, Interim Consultation Procedure With Treaty 8 First Nations (1 April 2011), online: OGC $<$ http://www.bcogc.ca/firstnations/consult.aspx $>$ [ICP].

Ibid at 4. The ICP therefore does not apply to the Blueberry River First Nation, which is party to a Long Term Oil and Gas Agreement, and the Dene Tha' and McLeod Lake First Nations, whose CPAs have not yet expired.

OGC, Information Bulletin 2011-08, “Interim Consultation Procedures in Effect” (1 April 2011), online: OGC <http://www.bcogc.ca/publications/infobulletin.aspx> .

Ibid.

Ibid.

Ibid.

Under Phase 3 of the ICP, for example, the OGC will, on receipt of a First Nation response to a proposed activity, conduct a preliminary assessment of further appropriate consultation levels and accommodation. The OGC, proponent, and First Nations are then to discuss accommodation options. These discussions will either lead to an agreement, or they will not. If the latter, the ICP requires the OGC to review sticking points and assess whether they can be overcome. Assuming this is unsuccessful, the OGC must then assess whether the consultation process thus far has been sufficient to satisfy the Crown's constitutional obligations, and if not, it must re-engage in consultation. If an agreement is still not reached, the OGC will consider engaging in an issue resolution process, such as agreeing to a First Nation's request for a meeting between the chief and the Deputy Commissioner or Commissioner prior to making a decision. ICP, supra note 121 at 9-11.

See e.g. the McLeod Lake Indian Band Consultation Process Agreement at 21, online: OGC <http:// www.bcogc.ca/firstnations/consult.aspx>. 


\section{The Possibility of Litigation}

It seems that First Nations are considering litigation as a strategic option to ensure enhanced consultation and accommodation on the part of the Crown. A recent news report of First Nations dissatisfaction with the CPAs stated:

Tim Thielmann is a lawyer representing the West Moberly and Halfway River First Nations and he said without a CPA, industry and government will have no concrete timelines on how quickly First Nations will be able to assess a proposal's impact on their treaty rights.

"It falls back onto the constitutional obligation for government to consult and accommodate First Nations prior to development on their traditional lands,” said Thielmann.

That legal obligation was set down by the Supreme Court in 2004 in the Haida case, where the justices ruled that government has a duty to consult [on] traditional or contested Aboriginal territory subject to development.

"Industry could expect significant delays and First Nations will be able to challenge the legal status of a project if the OGC doesn't adequately consult,” explained Thielmann.

“The courts can suspend the approval and that's the danger to industry and government if they don't do something."

Essentially, the CPA, which streamlined the relationship between First Nations, industry and government, has expired and now each project could be subject to the individual scrutiny of the courts.

The sticking point for the Treaty 8 Bands, said [Treaty 8 Chief] Logan, is that the OGC needs to look at the cumulative impact of the projects they approve.

She said the OGC currently approves projects based on their individual merits without assessing how the 32,000 wells [affect] the environment as a whole. ${ }^{129}$

\section{Contaminated Sites}

\section{A. INTRODUCTION}

Soil and groundwater contamination in the NEBC oil patch is regulated by the contaminated sites regime in the Environmental Management Act, ${ }^{130}$ and the supporting Contaminated Sites Regulation. ${ }^{131}$ The EMA and CSR are highly prescriptive, and are further supported by detailed protocols and guidance documents published by the Ministry of Environment (MOE). ${ }^{132}$

$129 \quad$ Lux, supra note 119.

$130 \quad$ SBC 2003, с 53 [EMA].

$131 \quad$ BC Reg 375/96 [CSR].

132 British Columbia's regime shares some features found in the US federal Superfund legislation, 42 USC $\S \S 9601-75$ (2011), and state analogs. Alberta's contaminated sites legislation adopts some of these US principles, but not to the extent found in British Columbia. Unlike Alberta's contaminated sites legislation, British Columbia creates a special cause of action (usually used to supplement common law 
The contaminated sites regime in NEBC is jointly administered by two government bodies - the MOE and the OGC. The two agencies' respective roles are formalized with a memorandum of understanding. ${ }^{133}$ The OGC is responsible for the approval of certificates of restoration ${ }^{134}$ (CoR) - the instrument for approving remediation in the oil patch - and several other administrative matters, but most of the regulatory changes are driven by the MOE, which retains the authority to take enforcement action through remediation orders and other measures.

The British Columbia contaminated sites regime has continuously evolved since 1997. Changes will likely continue, especially after a recent strongly worded critique by the provincial Auditor General that the OGC should improve its regulatory oversight of oil patch contamination problems. ${ }^{135}$ An underlying theme of this critique was that deficient regulatory responses to emerging contamination problems may further increase taxpayer liability for orphan sites on the oil patch.

As discussed below, several recent changes have had significant practical liability implications for oil patch operations, and contemplated changes are also potentially significant.

\section{B. RECENT NEW STANDARDS OF “CONTAMINATION”}

The EMA and the CSR use numeric "part-per-million" standards to define contamination. ${ }^{136}$ The definitions of "contamination" and “contaminated site” are not merely technical matters - they determine the scope of liability, as the EMA liability scheme attaches only to sites found to include "contamination." ${ }^{137}$ Questions over "contamination" are therefore central considerations in both of the EMA liability-setting mechanisms, namely: (a) a statutory cause of action enabling parties who incur "remediation costs" at a "contaminated site" to recover those costs in a civil action from "responsible persons" (in addition to tort remedies available to the plaintiff); and (b) the MOE regulator's issuance of a remediation order against persons responsible for a “contaminated site."138

The importance of “contamination” within an oil patch fracking context is illustrated in a recent claim filed in the Alberta Court of Queen’s Bench, namely Jessica Ernst $v$ Encana

actions) enabling persons to recover "remediation costs" from "responsible persons.” See EMA, supra note 130 , s 47.

Government of British Columbia, Provincial Sub-Agreement Memorandum of Understanding between the Oil and Gas Commission, Ministry of Environment, Ministry of Agriculture and Lands and the Ministry of Energy, Mines and Petroleum Resources (5 August 2008), online: OGC <http://www. bcogc.ca/documents/newsreleases/Archives/MOU\%20OGC\%20MoE\%20MAL\%20 MEMPR.pdf>. The EMA and the CSR formally allow parties to select one of two standards when remediating a site. An OGC CoR may be issued to indicate that contamination has been satisfactorily remediated. The "riskbased remediation standard" contemplates that contaminants may be left onsite if properly managed. The other remediation standard, the "numerical standard," requires removal of the contaminant. See supra notes 130-31.

Office of the Auditor General of British Columbia, Oil and Gas Site Contamination Risks: Improved Oversight Needed, Report 8 (Victoria: Office of the Auditor General, 2010).

By comparison, Alberta does not formalize standards of contamination in a regulation but relies on guidance documents.

Supra note 130, s 45 .

Ibid, s 48. This is unlike many other Canadian jurisdictions, including Alberta, which rely on guidelines, criteria, and similar subjective criteria by regulators. 
Corp. ${ }^{139}$ The Ernst Civil Action alleges, in part, that fracking operations by EnCana Corp caused actionable damages, pointing to various forms of soil and groundwater contamination. The Ernst Civil Action is at a very early stage, but it does illustrate that such claims are not a remote possibility in NEBC, particularly where surface land owners are concerned that the OGC and the MOE are not taking enough enforcement action against fracking operations.

Indeed, it is arguable that NEBC operators are more exposed under British Columbia's EMA than under Alberta legislation for the following reasons:

1. Fracking fluids would likely be caught as "contaminants" under the British Columbia contaminated sites regime, given that the CSR captures hundreds of chemical substances in groundwater, soil, and vapour media. The determination of whether groundwater, soil or vapour is contaminated in British Columbia is not a matter of subjective discretion of a regulator using mere guidelines. In British Columbia, the CSR, not a regulator or a policy guidance document, deems what is "contamination.” In contrast, the Ernst Civil Action will likely be concerned with whether certain concentration levels in soil and groundwater amount to actionable contamination (which may pose a more difficult evidentiary burden for plaintiffs in Alberta); and

2. Down-gradient plaintiffs in British Columbia could rely on the above-noted EMA statutory cause of action to recover remediation costs without facing the tort evidentiary burden of proving who caused the contamination at the source site. That is, in British Columbia, on finding contamination at his or her property, a plaintiff is required to prove that it migrated from the up-gradient site, and on that basis alone can name one or more "responsible persons" at that site (typically owners and operators, subject to certain exemptions) as defendants, who in turn can be held jointly and severally, absolutely, and retroactively liable. ${ }^{140}$ Unlike tort law principles that will govern the Ernst Civil Action, the plaintiff under the EMA does not have to prove that a particular defendant actually caused the contamination; it is enough to prove that the defendant falls within the "responsible person" definition.

In the past two years, the MOE has led law reform initiatives that have resulted in stricter standards which collectively broaden the net of contaminated sites that are subject to the EMA liability scheme. These changes are summarized below. 00120 (21 April 2011) [Ernst Civil Action].

140 The EMA cause of action will likely be more attractive to aggrieved parties in the Peace River Block (as opposed to the Horn River Basin and Liard-Besa areas) because surface landowners in that area tend to be private owners. In the Horn River and Liard-Besa areas, the Crown enjoys the right to issue remediation orders to effect cleanup without having to incur the time and cost of using an EMA cost recovery action (although the cost recovery action is available to the Crown irrespective of whether a remediation order is issued). 


\section{SOIL VAPOUR STANDARDS}

Before 2009, numerical standards of contamination were cast with reference to soil or groundwater media. Amendments to the CSR in 2009 added soil vapour as a regulated environmental medium. ${ }^{141}$ That is, a site can be determined to be "contaminated" on the basis of air quality, irrespective of whether origin soil does not exceed the applicable numeric standards prescribed in the CSR.

\section{NON-AQUEOUS PHASE LIQUIDS (NAPLS)}

These liquids are commonly used and found in oil patch activities and tend to be highly mobile, and thus NAPLs can migrate considerable horizontal and vertical distances. The MOE's Protocol 16 for Contaminated Sites: Determining the Presence and Mobility of Nonaqueous Phase Liquids and Odorous Substances clarifies when such liquids become "contaminants." ${ }^{142}$ In practical terms, Protocol 16 seeks to remove doubt as to whether NAPL contamination exists, and for this reason, will likely cause more sites to be deemed “contaminated.”

\section{STRICTER APPROACHES FOR INVESTIGATING POTENTIAL GROUNDWATER CONTAMINATION}

The MOE has embarked on an ambitious plan to revamp guidance for applying standards to groundwater. As part of this plan, the MOE published new guidance in Technical Guidance Documents 6 and 8, which came into effect on 1 February 2011. ${ }^{143}$ Guidance Document 8 ("Groundwater Investigation and Characterization”) is the more important of the two, as it will have a direct bearing on determining if a site is "contaminated" and, for such sites, whether studies supporting a remediation effort are satisfactory.

\section{Liability Management Rating Program}

On 28 October 2010, the OGC introduced new rules requiring oil patch operators, upon applying for a wide range of oil patch activities, to furnish security that might ultimately be used to remediate contamination. The gist of this program is described by the OGC as follows:

The [Liability Management Rating (LMR)] is the calculated ratio of deemed assets to deemed liabilities for permit holders. The intent of the LMR program is to identify permit holders whose liabilities exceed assets (a LMR of less than 1.0) and to require that permit holder to take steps to address or mitigate any financial risks inherent in the calculation. ${ }^{144}$

BC Reg 375/96, as amended by BC Reg 343/2008, s 1.

British Columbia Ministry of Environment, Protocol 16 for Contaminated Sites: Determining the Presence and Mobility of Nonaqueous Phase Liquids and Odorous Substances (Victoria: Ministry of Environment, 2010) [Protocol 16].

British Columbia Ministry of the Environment, Technical Guidance 6 on Contaminated Sites: Water Use Determination (Victoria: Ministry of Environment, 2011); British Columbia Ministry of the Environment, Technical Guidance on Contaminated Sites: Groundwater Investigation and Characterization (Victoria: Ministry of Environment, 2011).

OGC, Information Bulletin 2010-23, “Liability Management Rating Program” (14 October 2010) at 1. 
The LMR is calculated with respect to all wells and facilities registered to a permit holder, without consideration for a permit holder's working interest. ${ }^{145}$

\section{E. New Rules Addressing OfF-Site Migration}

British Columbia's contaminated sites regime includes two recent changes designed to compel parties to identify and address contamination migrating from source sites to neighbouring lands. One set of changes requires that source site owners or operators notify neighbours of contamination found to be migrating from their sites. The MOE also receives such notifications. These notification rules are found in sections 57(1.1) and 60.1 of the CSR. ${ }^{146}$ The notifications give potentially affected down-gradient neighbours information from which to conduct their own investigations on their properties and assess their legal strategies. As discussed under Part V.B, one such legal option is to take advantage of the EMA cost recovery cause of action (in addition to tort causes of action). Moreover, the offsite notification also can be used by the MOE to assess whether the migration of contamination creates a risk to human health or the environment, in which case it may consider issuing a remediation order against "responsible persons" at the source property.

The second change pertains to MOE and OGC policy criteria for approving remediation. Owners and operators of contaminated sites in the oil patch are generally not required to obtain CoRs, but the need to remove environmental liability from the corporate books is an incentive for seeking CoRs. CoR applicants must not only remediate their source sites, they must "address" potential off-site migration. ${ }^{147}$ In many cases, addressing the off-site migration means that the CoR-holder must commit to first delineate and then remediate the off-site. Thus, even absent a cost recovery or tort civil action brought by a down-gradient neighbour, the source site owner may be responsible for the migrating contamination as a condition of receiving a CoR. ${ }^{148}$

\section{F. NEW MEANS OF IDENTIFYING RISK}

The OGC's Site Classification Tool requires that site operators, in prescribed instances, classify their sites by degree of risk. ${ }^{149}$ Findings of "high risk" can in turn trigger certain further investigation or remedial action. The Classification Tool generally applies the MOE's Protocol 12 for Contaminated Sites: Site Risk Classification, Reclassification and Reporting approach to the oil patch. ${ }^{150}$

Ibid. Liabilities are calculated based on a schedule of unit costs for various facilities. For example, an active well has an abandonment unit cost of $\$ 75,000$ and a reclamation unit cost of $\$ 75,000$, while a compressor station has an abandonment unit cost of $\$ 15,000$ and a reclamation unit cost of $\$ 75,000$. Assets are calculated using the equation "Assets = Annual Production * Industry Netback * Return Period" (ibid at 2).

146 Supra note 131.

147 British Columbia Ministry of Environment, Protocol 6 for Contaminated Sites: Eligibility of Applications for Review by Approved Professionals (Victoria: Ministry of Environment, 2010).

Ibid.

OGC, Upstream Oil and Gas Classification Tool (Victoria: OGC, 2009).

British Columbia Ministry of Environment, Protocol 12 for Contaminated Sites: Site Risk Classification, Reclassification and Reporting (Victoria: Ministry of Environment, 2010). 


\section{G. ORPHAN SITES}

An important contaminated sites measure respecting orphan sites was enacted in 2006 under the now-repealed Oil and Gas Commission Act, and subsequently rolled into the $O G A A$ as sections 40 to 47 . Under sections 44 to 47 of the OGAA, the OGC may designate a well, facility, or pipeline an "orphan site" if the operator is insolvent or the commission cannot identify the operator. Likewise, an area can be designated an orphan site if it requires restoration from an oil and gas activity by an insolvent or unidentified person. Section 45 specifies that the OGC may restore orphan sites using the orphan sites fund (the Fund) created by the former PNGA and continued by section 45(3) of the OGAA. Section 46 provides for compensation to affected landowners. The OGC has a right of action in debt against a current or previous operator of an orphan site for the recovery of any compensation or restoration expenditures from the Fund. In addition to the recovery of those debts, the Fund is primarily financed with the orphan site restoration tax on petroleum and natural gas producers, the details of which are set out in section 47 . The tax rate is currently set at three cents per 1,000 cubic metres of marketable gas produced per month and six cents per cubic metre of petroleum produced per month. ${ }^{151}$

\section{CONCLUSION}

The significance of the four above-noted sets of changes can be illustrated by comparing the regulatory regime today with what existed ten years ago. Ten years ago, fracking in NEBC was generally not used. This unconventional technology ushered in a new era of production in NEBC - and several new contentious issues as well. Concerns over fracking likely contributed to the overhaul of the decades-old PNGA. The OGAA incorporated pre2010 fracking provisions and added others. The OGC appears to have significant new powers to do so - the OGAA affirms the government intention to position the OGC as a super agency, especially given the host of new regulation-making and enforcement powers. But the public criticism in British Columbia (and many other jurisdictions) of fracking is not abating, and may prompt further regulatory responses. The OGC has already signalled that it will introduce further measures to address fracking.

Groundwater extraction for gas production was not an issue ten years ago in NEBC. In the coming year or two, there could be a new cornerstone to the regulatory regime - a MOE groundwater licencing regime. A groundwater licencing regime has the potential for significantly affecting how much groundwater can be used for oil and gas activities, and it could mark a stronger MOE presence in the NEBC oil patch, perhaps diminishing the central agency role of the OGC. A key legal issue likely to be considered in the current law reform process is what redress oil patch operators can pursue in the event that groundwater licences have the effect of substantially abrogating pre-existing extraction rights.

Courts over the past ten years have provided substantially more guidance on the constitutional duty of the Crown to consult and accommodate First Nations. This is particularly evident in NEBC, where a number of decisions have pointed to the need for improved consultation and accommodation; the considerable risk of failed consultation and 
accommodation takes the form of rescinded or suspended approvals. Undertaking meaningful consultation and accommodation represents a significant challenge to all parties (First Nations, the Crown, and industry), particularly at a time of hectic oil and gas activity with over a thousand oil and gas activity applications a year (aside from other decisions not subject to CPAs). The 2006 CPAs did provide, at least for industry, some measure of certainty.

We are now in a different era, however. It is difficult to assess what lies ahead in the coming months. A full range of outcomes is possible. Current negotiations might result in the far more comprehensive successor to the expired CPAs. Failure to conclude such agreements may prompt First Nations to litigate, alleging that, absent the expired CPAs, there has not been adequate consultation respecting the many oil and gas activity applications or that there might be a new deal for consultation and accommodation. One thing is certain in this transition time: following the template of the recently expired CPAs is not on the table. A much deeper form of consultation is required by First Nations.

The "sleeper" in the regulatory changes pertains to a series of contaminated sites provisions, largely at the initiative of the MOE. The measures collectively bring more - and stricter - definition to the conditions that give rise to the existing liability principles adopted in the contaminated sites regime in 1997. The EMA liability principles (found in the cause of action and order power provisions) will apply to more sites with the increased scope of contamination. That is, liability exposure for contaminated sites has increased in recent years. The Ernst Civil Action illustrates how civil actions will be increasingly considered to seek damages for environmental problems attributable to fracking. Arguably, such recourse is more available in British Columbia than in Alberta. 